\title{
THE IMPROVEMENT ABILITY OF CALCULATING DIVISION USED UNO CARD IN MATHEMATIC
}

\section{Solikhatul Putri Amelia,Sukarno,Siti Wahyuningsih}

Universitas Sebelas Maret ameliasp19967@gmail.com

\section{Article History}

accepted 09/07/2018

approved 01/08/2018

published 17/09/2018

\section{Keywords}

UNO card, ability of

calculating, division

\begin{abstract}
The purpose of this research was to improve ability of division used UNO card on mathematic of second grades primary school. The data collect technique used interview, observation, test, and documentation. Validity technique used content validity, triangulation of sources, and triangulation of technique. Data analisys used interactive model. Finding indicated that, the application of UNO card can be used to improve ability division. In the beginning, the learning completness was $21,74 \%$. In the first cycle the learning completness improve became $60,87 \%$, in second cycle improve became $91,30 \%$.
\end{abstract}

Social, Humanities, and Education Studies (SHEs): Conference Series https://jurnal.uns.ac.id/shes
p-ISSN 2620-9284

e-ISSN 2620-9292 


\section{PENDAHULUAN}

Kemampuan menghitung pembagian merupakan salah satu kompetensi yang perlu dikuasai pada matematika. Sebelum siswa dapat menghitung pembagian, siswa harus menguasai operasi hitung pengurangan terlebih dahulu sebagai dasar dari pembagian. Sama halnya dengan Ping dan Hua (2015) yang mengungkapkan konsep dari operasi pembagian penting karena merupakan dasar agar siswa dapat menjadi lebih pandai. Siswa tidak boleh hanya dituntut untuk menghafal karena akan menyebabkan siswa kesulitan ketika menjumpai soal yang berbeda. Namun, pada kenyataannya, kemampuan menghitung siswa masih rendah. Sebagian besar siswa belum dapat menerapkan konsep dari pembagian, yaitu pengurangan berulang. Penggunaan media yang masih sangat terbatas menjadi penyebab randahnya kemampuan siswa untuk melakukan operasi hitung pembagian. Hasil pretest diperoleh hanya 5 siswa atau $21,74 \%$ dari 23 siswa yang mencapai nilai KKM $(\geq 70)$. Terkait hal tersebut, dibutuhkan adanya perbaikan dengan cara usaha perbaikan pada media pembelajaran dengan media pembelajaran yang inovatif, yaitu UNO card.Terkait hal tersebut, kekurangan dalam pembelajaran dapat diatasi dengan adanya inovasi media pembelajaran, yaitu UNO card.

Menurut Rohrig (2008) UNO card merupakan permainan kartu keluarga yang menggunakan peraturan permainan yang mudah untuk siapapun di atas umur 7 tahun. UNO card merupakan permainan kartu yang hampir sama dengan kartu remi biasa. Cara menggunakan UNO card yaitu hanya dengan mencocokkan warna atau angka yang tertera pada kartu. Selain itu, dalam UNO card terdapat tambahan kartu, yaitu action cards. Macam-macam action cards yaitu skip card, reverse card, draw two card, wild draw four card, dan wild card. Satu set UNO card berjumlah 108 kartu. Hal ini diperkuat oleh Chen (2017) yang menyatakan, "... UNO has 108 cards, whereas TCGs always has..." yang berarti jumlah UNO card sebanyak 108. UNO card terdiri dari 4 macam warna, yaitu merah, kuning, hijau, dan biru (Sari dan Luthfi, 2015). UNO card pada penelitian ini sedikit berbeda dengan yang dijual dipasaran karena UNO card yang akan digunakan sebagai media pembelajaran kelas II yang merupakan media pembelajaran pembagian bagi sisiwa kelas II sehingga UNO card yang digunakan dalam penelitian ini sedikit dimodifikasi. Angka pada UNO card yang digunakan dalam penelitian ini diganti menjadi soal pembagian yang dimainkan oleh siswa sehingga siswa dapat belajar sambil bermain. Landasan peneliti melakukan modifikasi yaitu karena telah diadakannya modifikasi serupa oleh Sriyati (2016) yang memodifikasi UNO card sebagai alternatif bahan pembelajaran penjumlahan dan pengurangan bagi siswa kelas I Sekolah Dasar.

Penggunaan media UNO card dijelaskan oleh Ramadhan, dkk (2015) bahwa Pertama, permainan dimulai dengan menentukan siapa di antara peserta yang akan bermain terlebih dahulu. Pada bagian ini, setiap pemain memilih kartu dan pemain pertama ditentukan oleh orang yang mendapatkan jumlah kartu bernomor tertinggi. Kemudian, setiap pemain saat memulai giliran pertamanya harus menentukan apakah dia ingin menggambar kartu, atau memainkan kartu di tangannya. Dia dapat memilih untuk memainkan kartu di tangannya, jika tidak, dia mengeluarkan kartu dari tumpukan kartu yang tertutup dan bisa memainkan kartu yang ditarik jika kartu itu memungkinkan dimainkan. Pada peraturan resmi, permainan berakhir sampai ada satu pemain yang tidak memiliki kartu tersisa di tangannya. Namun, Ramadhan, dkk (2015) juga menjelaskan bahwa peraturan permainan UNO dapat dimodifikasi pula karena terdapat beberapa pendapat yang sedikit berbeda. Berdasarkan hal tersebut, peneliti juga memodifikasi peraturan permainan UNO card dalam pembelajaran. Langkah-langkah permainan UNO card pada penelitian ini yaitu, (1) masing-masing kelompok mendapat 4 kartu; (2) masing-masing perwakilan kelompok gambreng untuk menentukan pemain pertama yang mengeluarkan kartu; (3) guru mengambil satu kartu dari tumpukan kartu; (4) pemain pertama harus mengeluarkan kartu yang warna atau angkanya sama, jika 
pemain tersebut tidak mempunyai warna atau angka yang sama maka harus mengambil satu kartu dari tumpukan kartu. Pada bagian ini siswa dituntut harus dapat menghitung pembagian bilangan dengan bilangan satu angka. Namun, apabila siswa tidak dapat menghitung pembagian yang ada pada UNO card, siswa dapat menghitung pembagian dengan cara pengurangan berulang sampai habis atau dengan cara pendekatan himpunan. Siswa dituntut untuk menghitung pembagian karena pada UNO card terdapat soal pembagian yang harus dihitung oleh siswa; (5) permainan berakhir dengan batasan waktu 30 menit atau apabila terdapat satu kelompok yang tidak memiliki satupun kartu UNO card dan kelompok tersebut dianggap sebagai pemenang.

UNO card masuk dalam kategori flashcard yang mana UNO card mempunyai kelebihan (1) bersifat praktis; (2) mudah dibawa kemana-mana; (3) mudah diingat karena terdapat gambar dan angka sehingga dapat membuat daya ingat menjadi lebih lama; (4) menyenangkan (Indriana, 2011). Adanya gambar yang terdapat pada UNO card juga dapat mengaktifkan otak kanan, sehingga tidak hanya otak kiri saja yang bekerja. Pembelajaran dengan mengaktifkan otak kanan dan kiri tentunya akan menjadi lebih baik jika dibandingkan pembelajaran hanya menggunakan otak kiri saja.

Berdasarkan uraian yang telah dijelaskan di atas maka peneliti melakukan penelitian dengan judul "Peningkatan Kemampuan Menghitung Pembagian Melalui Media UNO Card pada Siswa Kelas II SD N Tegalsari Tahun Ajaran 2017/ 2018". Peneliti juga menyusun rumusan masalah yaitu, "Apakah penggunaan media UNO card dapat meningkatkan kemampuan menghitung pembagian pada siswa kelas II SD N Tegalsari Tahun Ajaran 2017/ 2018 dan Bagaimanakah peningkatan kemampuan menghitung pembagian pada siswa kelas II SD N Tegalsari tahun ajaran 2017/ 2018?" berdasarkan rumasan masalah tersebut, maka tujuan penelitian yaitu untuk meningkatkan kemampuan menghitung pembagian pada siswa kelas II SD N Tegalsari tahun ajaran 2017/ 2018.

\section{METODE}

Penelitian ini menggunakan pendekatan kualitatif, sedangkan jenis penelitian ini yaitu Penelitiain Tindakan Kelas (PTK) yang terdiri dari empat langkah, yaitu perencanaan, pelaksanaan, observasi/ pengamatan, dan refleksi (Sukardi, 2012). Subjek pada penelitian ini yaitu guru kelas II dan seluruh siswa kelas II SD N Tegalsari yang berjumlah 23 siswa (9 laki-laki dan 14 siswa perempuan). Teknik pengumpulan data pada penelitian ini menggunakan wawancara, observasi, tes, dan dokumentasi. Uji validitas data menggunakan validitas isi dan triangulasi sumber serta triangulasi teknik. Teknik analisis data menggunakan model interaktif Miles dan Huberman (2014) yang terdiri dari, pengumpulan data, reduksi data, penyajian data, dan penarikan kesimpulan.

Indikator kinerja penelitian yaitu menghitung pembagian bilangan dengan bilangan satu angka dan menghitung pembagian bilangan sampai dua angka dengan berbagai cara. Penelitan dikatakan berhasil apabila $80 \%$ atau 18 siswa telah mencapai $\operatorname{KKM}(\geq 70)$.

\section{HASIL DAN PEMBAHASAN}

Penelitian ini dilaksanakan selama 2 siklus dimana setiap siklus terdiri dari dua pertemuan. Alokasi waktu satu pertemuan yaitu 2x35menit. Materi pada siklus I dan siklus II yaitu menghitung pembagian. Pada siklus I pertemuan pertama indikator pembelajaran yaitu menghitung pembagian bilangan dengan bilangan satu angka. Pada siklus I pertemuan kedua indikator pembelajaran yaitu menghitung pembagian bilangan sampai dua angka dengan berbagai cara. Indikator pada siklus II pertemuan pertama maupun pertemuan kedua sama dengan siklus I, yang membedakan adalah tingkat kesulitan soal pada siklus II. Model pembelajaran yang digunakan pada siklus I 
dan siklus II menggunakan model pembelajaran kooperatif. Media pembelajaran yang digunakan pada siklus I dan siklus II menggunakan media UNO card.

Hasil observasi dan wawancara dengan guru dan salah satu siswa kelas II SD N Tegalsari, diperoleh informasi bahwa masih banyak siswa yang kesulitan dalam menghitung sehingga mengakibatkan siswa merasa takut pada mata pelajaran Matematika, khususnya pembagian dalam mengikuti pembelajaran. Antusiasme siswa dalam pelajaran Matematika sangatlah kurang, karena Matematika merupakan pelajaran yang dianggap sulit. Pembelajaran pada pelajaran Matematika cenderung menegangkan dan membuat siswa jenuh serta cepat bosan. Pada kenyataanya, siswa kelas II sebenarnya merupakan usia dimana anak-anak masih suka bermain.

Setelah diadakannya wawancara dan observasi peneliti kemudian melakukan pratindakan berupa pre-test. Hasil observasi ketuntasan siswa pada saat pratindakan diperoleh rata-rata nilai kelas yaitu 56,52 dengan ketuntasan klasikal sebesar 5 siswa atau $21,74 \%$ dari 23 siswa, sedangkan 18 siswa atau 78,26\% dari 23 siswa belum mencapai KKM (KKM $\geq 70)$. Pada siklus I rata-rata nilai kemampuan menghitung pembagian siswa meningkat menjadi 73,26 dengan ketuntasan klasikal sebesar $60,87 \%$ atau 14 siswa telah mencapai KKM, sedangkan $39,13 \%$ atau 9 siswa belum mencapai KKM. Pada siklus II rata-rata nilai kemampuan menghitung pembagian meningkat lagi menjadi 86,30 dengan ketuntasan klasikal sebesar 91,30\% atau 21 siswa telah mencapai KKM, sedangkan $8,70 \%$ atau 2 siswa belum mencapai KKM. Hasil nilai kemampuan menghitung pembagain pada pratindakan, siklus I, dan siklus II sebagai berikut:

Tabel 1. Perbandingan Rata-rata Nilai Kemampuan Menghitung Pembagian Siswa Kelas II Pratindakan, Siklus I, dan Siklus II

\begin{tabular}{|c|c|c|c|c|c|c|}
\hline \multirow{2}{*}{$\begin{array}{c}\text { Interval } \\
\text { Nilai }\end{array}$} & \multicolumn{2}{|c|}{ Pratindakan } & \multicolumn{2}{|c|}{ Siklus I } & \multicolumn{2}{|c|}{ Siklus II } \\
\hline & $\begin{array}{l}\text { Frekuensi } \\
\text { (fi) }\end{array}$ & $\begin{array}{l}\text { Persentase } \\
(\%)\end{array}$ & $\begin{array}{l}\text { Frekuensi } \\
\text { (fi) }\end{array}$ & $\begin{array}{l}\text { Persentase } \\
(\%)\end{array}$ & $\begin{array}{l}\text { Frekuensi } \\
\text { (fi) }\end{array}$ & $\begin{array}{l}\text { Persentase } \\
\text { (\%) }\end{array}$ \\
\hline $24-34$ & 2 & 8,70 & 0 & 0 & 0 & 0 \\
\hline $35-45$ & 6 & 26,08 & 1 & 4,35 & 1 & 4,35 \\
\hline $46-56$ & 5 & 21,74 & 5 & 21,74 & 0 & 0 \\
\hline $57-67$ & 5 & 21,74 & 3 & 13,04 & 1 & 4,35 \\
\hline $68-78$ & 0 & 0 & 4 & 17,39 & 2 & 8,69 \\
\hline $79-89$ & 3 & 13,04 & 4 & 17,39 & 9 & 39,13 \\
\hline $90-100$ & 2 & 8,70 & 6 & 26,09 & 10 & 43,48 \\
\hline Jumlah & 23 & 100 & 23 & 100 & 23 & 100 \\
\hline \multirow{2}{*}{\multicolumn{2}{|c|}{$\begin{array}{c}\text { Nilai Rata-rata } \\
\text { Nilai Ketuntasan } \\
\text { Klasikal }\end{array}$}} & 56,52 & \multicolumn{2}{|c|}{73,26} & \multicolumn{2}{|c|}{86,30} \\
\hline & & $21,74 \%$ & \multicolumn{2}{|c|}{$60,87 \%$} & \multicolumn{2}{|c|}{$91,30 \%$} \\
\hline
\end{tabular}

Berdasarkan tabel 1 di atas, menunjukkan bahwa nilai rata-rata kemampuan menghitung pembagian pada saat pratindakan masih tergolong rendah, yaitu 56,52. Hasil tes pratindakan menunjukkan hanya 5 siswa $(21,74 \%)$ dari 23 siswa yang memperoleh nilai di atas Kriteria Ketuntasan Minimal (KKM) yang telah ditetapkan sedangkan 18 siswa $(78,26 \%)$ siswa belum mencapai KKM $(\geq 70)$. Data pada tabel tersebut membuktikan perlu adanya perbaikan pada kemampuan menghitung pembagian pada siswa kelas II SD N Tegalsari tahun ajaran 2017/2018. Solusi yang tepat untuk mengatasi masalah di atas yaitu dengan penggunaan media pembelajaran 
UNO card yang mampu menciptakan suasana yang menyenangkan dalam proses pembelajaran dan mampu menumbuhkan keaktifan siswa. Penggunaan media UNO card diharapkan dapat meningkatkan kemampuan menghitung pembagian sehingga ketuntasan hasil belajar siswa kelas II dapat terapai. Adanya tindakan pada siklus I menggunakan media UNO card menunjukkan terjadinya peningkatan pada kemampuan menghitung pembagian siswa kelas II. Pada siklus I dapat dilihat bahwa nilai rata-rata kemampuan menghitung pembagian pada siklus I 73,26. Hasil tes pada siklus I sebanyak 14 siswa atau $(60,87 \%)$ yang memperoleh nilai di atas KKM, sedangkan siswa yang memperoleh nilai di bawah KKM sebanyak 9 siswa atau $39,13 \%$. Target dalam indikator kinerja $(80 \%)$ belum tercapai sehingga pembelajaran pada siklus I perlu untuk direfleksi dan dilakukan perbaikan untuk dilanjutkan pada siklus II. Lebih jelasnya, dapat diliahat pada gambar 1 di bawah ini.

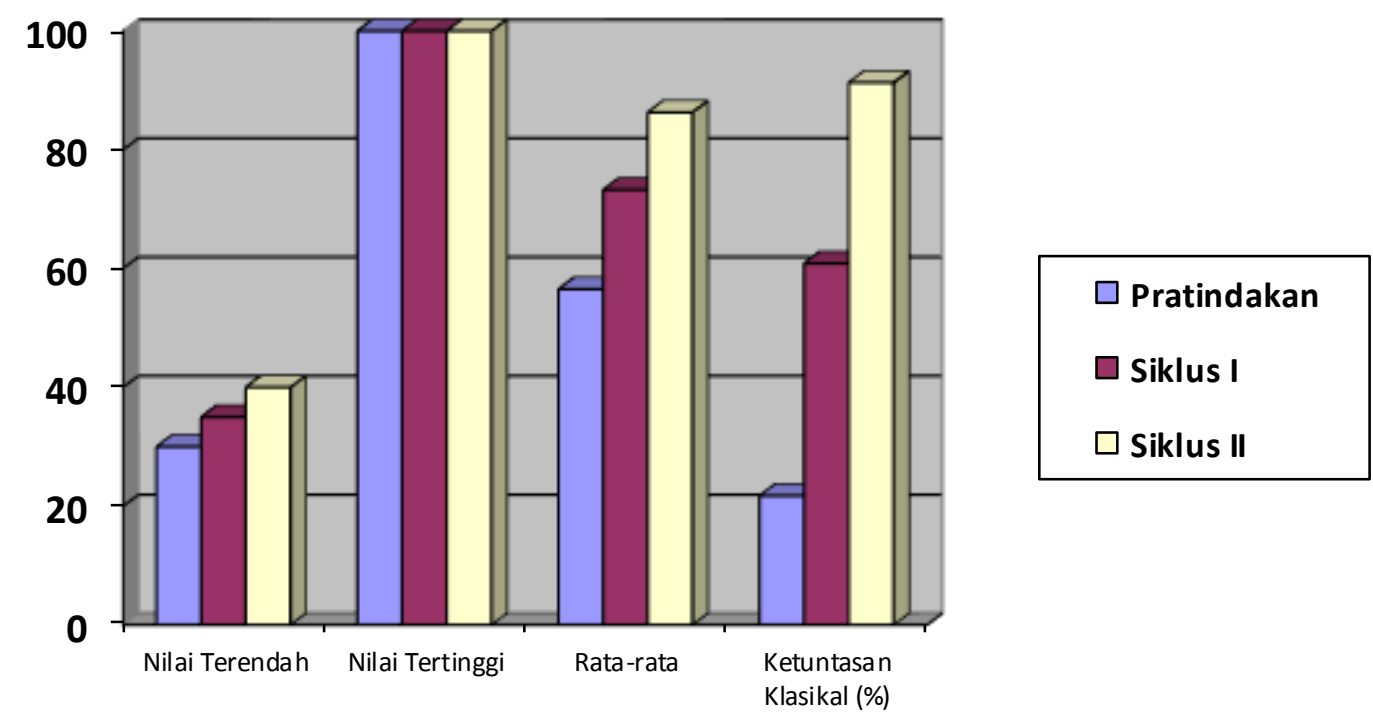

Gambar 1. Grafik Perbandingan Nilai Kemampuan Menghitung Pembagian Siswa Kelas II Pretest, Siklus I, dan Siklus II

Gambar 1 mengenai grafik perbandingan nilai kemampuan menghitung pembagian siswa kelas II menunjukkan adanya peningkatan. Pada pratindakan, nilai terendah diperoleh sebesar 30, kemudian setelah dilakukan tindakan menggunakan media UNO card meningkat pada siklus I menjadi 35, dan meningkat lagi pada siklus II menjadi 40. Nilai tertinggi pada pratindakan, siklus I, dan siklus II diperoleh nilai tetap, yaitu 100. Rata-rata nilai pada pratindakan diperoleh 56,52, kemudian meningkat menjadi 73,26 pada siklus. Pada siklus II rata-rata nilai kemudian meningkat dibanding siklus I, yaitu menjadi 86,30 . Ketuntasan klasikal pada pratindakan sebesar $21,74 \%$ atau hanya 5 siswa yang dapat mencapai KKM, sedangkan 78,26\% atau 18 siswa belum mencapai nilai KKM. Ketuntasan klasikal meningkat pada siklus I menjadi $60,87 \%$ atau 14 siswa telah mencapi nilai KKM, sedangkan $39,13 \%$ atau 9 siswa belum dapat mencapai KKM. Dengan demikian, indikator kinerja penelitian belum mencapai target dan tindakan dilanjutkan pada siklus II.

Pada siklus II ketuntasan klasikal meningkat lagi menjadi 91,30\% atau 21 siswa telah mencapai KKM, sedangkan $8,70 \%$ atau 2 siswa belum mencapai KKM. Terkait hal tersebut, indikator kinerja telah tercapai, bahkan melebihi yang ditargetkan sehingga tindakan dihentikan pada siklus II. Penyebab kedua siswa yang belum 
mencapai KKM tersebut adalah siswa lamban belajar. Usaha sudah dilakukan agar nilai kedua siswa tersebut meningkat, yaitu dengan memberikan tugas tambahan berupa latihan soal, namun tetap saja nilai yang diperoleh belum mencapai KKM. Peneliti menyerahkan kepada guru kelas agar segera ditindaklanjuti dengan mengupayakan kerjasama antara guru dan orang tua siswa untuk mendapat bimbingan khusus secara intensif dan selalu memotivasi siswa agar semangat dalam kegiatan pembelajaran.

\section{SIMPULAN}

Berdasarkan hasil analisis dan observasi, maka dapat disimpulkan penggunaan media UNO card dapat meningkatkan kemampuan menghitung pembagian siswa kelas II SD N Tegalsari tahun ajaran 2017/ 2018. Terkait dengan hasil penelitian tindakan kelas yang dilaksanakan pada siswa kelas II SD N Tegalsari, peneliti memberi saran 1) bagi guru, lebih meningkatkan kemampuan kompetensi profesionalnya agar pembelajaran dapat berlangsung menyenangkan, inovatif terhadap media pembelajaran yang digunakan dalam pembelajaran agar siswa mendapat pengalaman belajar yang bermakna, salah satunya dengan menggunakan media UNO card; 2) bagi sekolah, melakukan kegiatan pengembangan pembelajaran yang lebih inovatif dan kreatif, salah satunya menggunakan media UNO card sehingga dapat meningktan kualitas pembelajaran; 3) bagi peneliti lain, menggunakan variabel media UNO card untuk lebih memodifikasi lagi agar siswa menjadi lebih antusias dan bersemangat.

\section{DAFTAR PUSTAKA}

Chen, P., dkk. 2016. The Effectiveness of Using In-Game Cards as Reward. Research and Practice in Technology Enhanced Learning. Diperoleh pada 21 Oktober 2017, dari https://telrp.springeropen.com/articles/10.1186/s41039-017-0054-8.

Indriana, D. 2011. Ragam Alat Bantu Media Pengajaran. Yogyakarta: DIVA Press.

Miles, MB., \& Huberman, AM. (2014). Analisis Data Kualitatif. Terj. T. R. Rohidi. Jakarta: UI-Press. (Buku asli diterbitkan 1992).

Ping, O W dan Hua, A K. 2015. Effectiveness of Division Wheel in Basic Mathematics Operation Case Study: Primary School Perspective. IOSR-JRME, 5 (3), 52-56.

Ramadhan, A., Maulidevi, N. U., \& lida, H. 2015. Game Refinement Theory and Multiplayer Games: Case Study Using UNO. The Seventh Internationanl Conference on Information, Process, and Knowledge Management, hlm 119-125, IARIA.

Rohrig, P dan Clarke. 2008. 57 SF Activities For Facilitators and Consultants. German: Solutions Books.

Sari, R. R., \& Lutfi, A. 2015. Kelayakan Permainan UNO CARD sebagai Media Pembelajaran pada Materi Pokok Struktur Atom. UNESA Journal of Chemical Education, 4 (2), 186-194.

Sriyati, S. R., Sutarjo, A., \& Wardana, D. 2016. Modifikasi Permainan UNO sebagai Alternatif Bahan Pembelajaran Penjumlahan dan Pengurangan Bagi Siswa Kelas 1 Sekolah Dasar. Kalimaya, 4 (2), 1-10.

Sukardi. 2012. Metodologi Penelitian Pendidikan. Jakarta: PT Bumi Aksara. 